\title{
Effects of isoenergetic overfeeding of either carbohydrate or fat in young men
}

\author{
Ole Lammert ${ }^{1}$, Niels Grunnet ${ }^{2} *$, Peter Faber ${ }^{1}$, Kirsten Schroll Bjørnsbo ${ }^{1}$, John Dich ${ }^{2}$, \\ Lis Olesen Larsen ${ }^{3}$, Richard A. Neese ${ }^{4}$, Marc K. Hellerstein ${ }^{4}$ and Bjørn Quistorff ${ }^{2}$ \\ ${ }^{1}$ Department of Sports Sciences and Clinical Biomechanics, Faculty of Health Sciences, \\ University of Southern Denmark, Main Campus: Odense University, Denmark \\ ${ }^{2}$ Department of Medical Biochemistry and Genetics, Panum Institute, University of Copenhagen, Denmark \\ ${ }^{3}$ August Krogh Institute, University of Copenhagen, Denmark \\ ${ }^{4}$ Department of Nutritional Sciences, University of California, Berkeley, CA, USA
}

(Received 31 August 1999 - Revised 7 December 1999 - Accepted 11 January 2000)

\begin{abstract}
Ten pairs of normal men were overfed by $5 \mathrm{MJ} / \mathrm{d}$ for $21 \mathrm{~d}$ with either a carbohydrate-rich or a fatrich diet (C-and F-group). The two subjects in each pair were requested to follow each other throughout the day to ensure similar physical activity and were otherwise allowed to maintain normal daily life. The increase in body weight, fat free mass and fat mass showed great variation, the mean increases being $1.5 \mathrm{~kg}, 0.6 \mathrm{~kg}$ and $0.9 \mathrm{~kg}$ respectively. No significant differences between the C- and F-group were observed. Heat production during sleep did not change during overfeeding. The RQ during sleep was 0.86 and 0.78 in the C- and F-group respectively. The accumulated faecal loss of energy, DM, carbohydrate and protein was significantly higher in the C- compared with the F-group (30, 44, 69 and $51 \%$ higher respectively), whereas the fat loss was the same in the two groups. $\mathrm{N}$ balance was not different between the $\mathrm{C}$ - and F-group and was positive. Fractional contribution from hepatic de novo lipogenesis, as measured by mass isotopomer distribution analysis after administration of $\left[1-{ }^{13} \mathrm{C}\right]$ acetate, was 0.20 and 0.03 in the C-group and the F-group respectively. Absolute hepatic de novo lipogenesis in the $\mathrm{C}$-group was on average $211 \mathrm{~g}$ per $21 \mathrm{~d}$. Whole-body de novo lipogenesis, as obtained by the difference between fat mass increase and dietary fat available for storage, was positive in six of the ten subjects in the C-group (mean 332 (SEM 191)g per 21d). The change in plasma leptin concentration was positively correlated with the change in fat mass. Thus, fat storage during overfeeding of isoenergetic amounts of diets rich in carbohydrate or in fat was not significantly different, and carbohydrates seemed to be converted to fat by both hepatic and extrahepatic lipogenesis.
\end{abstract}

Overfeeding: De novo lipogenesis: Energy expenditure: Leptin: Faecal loss

Energy consumed as carbohydrate, fat or protein, is either lost, used for internal or external work or stored if in excess. Several studies indicate that human subjects have a preference for oxidation of protein and carbohydrate, and that fat ingested in surplus of energy demand is deposited (Jebb et al. 1996; Jéquier, 1998; Stubbs, 1998; Wolfe, 1998). In several recent reviews on weight gain and energy intake in man the importance of the fat: carbohydrate ratio in the food has been stressed (for example see Flatt, 1987, 1995; Swinburn \& Ravussin, 1993; Astrup \& Raben, 1995; Lissner \& Heitmann, 1995; Stubbs, 1998). Such a correlation between weight gain and the fat:carbohydrate ratio has been tentatively explained by a higher palatability of fat, a higher energy expenditure with carbohydrate (originating from a larger thermogenic effect of carbohydrates including a larger storage cost of deposition in comparison with fat), an increased activity of the sympathetic nervous system, and an induced higher physical activity level (for example see Astrup \& Raben, 1995; Lissner \& Heitmann, 1995). However, it is not clear whether overconsumption of isoenergetic amounts of fat or carbohydrate will result in different fat deposition. Fat deposition induced by overfeeding with a high-carbohydrate diet can occur either as a result of an increased direct storage of ingested triacylglycerol in adipose tissue and/or as a result of de novo lipogenesis (DNL) from ingested carbohydrate. The control of the relative contribution of these two processes in man is not well understood. DNL takes place in the liver and in adipose tissue, but is generally considered to be of too low a capacity to explain observed weight gain (Hellerstein et al. 1996). 
Short-term ingestion of a large amount of carbohydrate resulted in increased storage of glycogen with no or only very limited DNL (Acheson et al. 1982, 1984). In longer experiments with extreme carbohydrate overfeeding, however, DNL was not negligible (Schutz et al. 1985; Acheson et al. 1988). In addition Pasquet et al. (1992) found an increase in body fat mass after massive overfeeding of a diet rich in carbohydrate, likely to be caused mainly by DNL (see calculations in Hellerstein et al. 1996). In more recent experiments Horton et al. (1995) studied effects of a $50 \%$ increase in energy intake, provided either as carbohydrate or as fat. Although the subjects given a surplus of fat showed an initially higher increase in body weight, the body weight after $14 \mathrm{~d}$ intervention was the same in the two groups. DNL was not measured. Aarsland et al. (1997) found a DNL of about $170 \mathrm{~g} / \mathrm{d}$ in human subjects massively overfed with carbohydrate, predominantly in the form of intravenous glucose, where hepatic contribution accounted for only $2 \%$ of the total. Schwarz et al. (1995) fed $50 \%$ excess energy as carbohydrate and observed only modest increases in the absolute rate of hepatic DNL.

The aim of the present study was to investigate, in a period of 3 weeks, the effects of overfeeding of isoenergetic amounts of normal foods either high in carbohydrate or high in fat on body composition, heat production during sleep and hepatic and total DNL. The subjects of the study were non-obese young men and, in contrast to most previous studies, they were allowed to maintain a normal daily life. Similar physical activity of the carbohydrate- and the fatgroup was ensured by letting the subjects follow each other throughout the experimental period, i.e. in the daytime they were free to engage in whatever activities they could agree upon ('Siamese' activity twins). In addition to changes in body composition, energy expenditure (direct and indirect) at sleep and DNL, energy loss in faeces, $\mathrm{N}$ balance, and the concentration of glucose, insulin and leptin in plasma were measured.

\section{Design and methods}

\section{Study design}

The study was designed to evaluate the effects of isoenergetic overfeeding of either a high-fat or a high-carbohydrate diet with an intended daily food excess of $5 \mathrm{MJ}$. Twenty normal young men were studied. They were divided into pairs, and the experiment was carried out with one pair at a time. The intervention period was planned for $21 \mathrm{~d}$ preceded by a 2 -week period of recording habitual food intake. The study involved 3 phases. Phase 1, the prephase, lasted 10$14 \mathrm{~d}$. The subjects lived at home and registered their habitual food intake by weighing all food items eaten, as well as recording all drinks by content and volume. Phase 2 , baseline measurements, lasted $2-3 \mathrm{~d}$. The subjects moved into the department, living and acting as 'Siamese' activity twins. They ate their preferred meals while baseline data for the experiment were obtained. Detailed instructions for the daily routines regarding body composition measurement, food registration and consumption, and faeces and urine collections were given. During this period the baseline measurements were obtained. Phase 3, the intervention period, was scheduled for $21 \mathrm{~d}$. The energy intake was increased by $5 \mathrm{MJ}$ above the individual habitual energy intake as determined during phase 1 .

Each person in a pair was randomly assigned to the highcarbohydrate (C-group) or the high-fat diet (F-group), and denoted $\mathrm{C} 1-\mathrm{C} 10$ and F1-F10 respectively. All faeces and urine were collected during phase 3 . Daily measurements of body composition were obtained in the morning after voiding, and before any meals were taken. Once a week a full day was used for measurements of body composition by underwater weighing, hepatic DNL and blood variables. For logistic reasons phase 3 varied from 17 to $22 \mathrm{~d}$ for the ten pairs. All results presented are normalised to $21 \mathrm{~d}$.

\section{Subjects}

Twenty apparently healthy subjects (male university students) with no previous record of obesity, weight loss or other metabolic illnesses participated in the study. They were between 20 and 25 years of age with BMI between 19.7 and $25.4 \mathrm{~kg} / \mathrm{m}^{2}$. Subjects were paired according to habitual activity and body size. There were no statistically significant differences between the two groups with regard to age, height, body weight or fat mass (Table 1).

While living in the quarters of the department, the subjects conformed with the following restrictions. The subjects acted as 'Siamese' activity twins in order to have similar physical activity within the pair. Thus the pair had to spend the entire 3 weeks together. All meals were prepared and consumed at the department. All nights were spent in the department's quarters. Every second night each subject slept in a whole-body calorimeter where both direct and indirect energy expenditure were measured. The subjects went to bed and woke up according to their own schedules. The subject who woke up first called the other subject. All twenty subjects completed the experiment.

\section{Food intake}

Food intake was calculated as energy and nutrients by means of the food composition database Dankost 2000 (Dansk Catering Center A/S, Copenhagen, Denmark),

Table 1. Subjects characteristics at the start of the experimental period (phase 2)

(Mean values with their standard errors)

\begin{tabular}{|c|c|c|c|c|c|c|c|c|c|}
\hline \multirow[b]{2}{*}{ Subjects } & \multirow[b]{2}{*}{$n$} & \multicolumn{2}{|c|}{ Age (years) } & \multicolumn{2}{|c|}{ Body weight (kg) } & \multicolumn{2}{|c|}{ Height $(\mathrm{cm})$} & \multicolumn{2}{|c|}{ Fat mass $(\mathrm{kg})$} \\
\hline & & Mean & SEM & Mean & SEM & Mean & SEM & Mean & SEM \\
\hline $\mathrm{C} 1-\mathrm{C} 10$ & 10 & $22 \cdot 3$ & 1.7 & $76 \cdot 4$ & $8 \cdot 8$ & 183 & 5 & $12 \cdot 0$ & 3.4 \\
\hline $\mathrm{F} 1-\mathrm{F} 10$ & 10 & $22 \cdot 4$ & 1.9 & 73.4 & $6 \cdot 7$ & 181 & 7 & $10 \cdot 6$ & $2 \cdot 7$ \\
\hline
\end{tabular}


based on the Danish Food Composition Tables (Møller \& Saxholt, 1996). These food tables present data on metabolizable energy. We consider them equal to total energy intake because of evidence that the values reported in the tables are too high (Nielsen et al. 1995). In phase 3, the C-group received $78 \%$ of energy as carbohydrates, $11 \%$ of energy as protein and $11 \%$ of energy as fat, while the F-group received $58 \%$ of energy as fat, $11 \%$ of energy as protein and $31 \%$ of energy as carbohydrate. A dietitian managed the diet planning and provided recipes with measures and explanations for each of the meals. The recipes were in general similar for all the subjects in the $\mathrm{C}$-group and in the F-group, but were individually adjusted to provide approximately $5 \mathrm{MJ}$ above the habitual intake, as well as to account for individual tastes and preferences. The subjects did the shopping themselves, and during the meal preparations they weighed and recorded all food items in accordance with the recipes and instructions given. The research staff regularly, but unannounced, confirmed that the meal preparations and the recording of intake of food, drinks, snacks and sweets took place in accordance with the instructions.

\section{Analytical procedures}

Anthropometry. Subjects were weighed every morning on a Tanita body fat analyser TBF-305 (Tanita Corp., Tokyo, Japan) (impedance method). Data for body weight, fat free mass, fat mass, and total body water were obtained. The subjects' standing height was measured on the first day in the department, and this measurement was used in all the body composition calculations.

As a validation of the impedance method fat mass and fat free mass were also measured once weekly in the morning by underwater weighing (densitometry). The subject was placed in a sitting position, and the residual volume of the lungs during the submergence was determined with the $\mathrm{N}_{2^{-}}$ dilution method. The diluted air mixture was measured for its concentration of $\mathrm{O}_{2}$ and $\mathrm{CO}_{2}$ with a paramagnetic $\mathrm{O}_{2}$ analyser (Servomex OOA 184; Servomex Controls Ltd, Crowborough, Sussex, UK) and an infrared $\mathrm{CO}_{2}$ analyser (Beckman LB2; Sensormedics Corp., Anaheim, CA, USA). Both analysers were calibrated with air which had its content determined using micro-Scholander technique (Scholander, 1947). Density measurements were repeated at approximately $12 \mathrm{~min}$ intervals until at least three of them agreed within $0.0015 \mathrm{~g} / \mathrm{ml}$.

Energy expenditure. Sleeping energy expenditure (SEE) was measured directly $\left(\mathrm{SEE}_{\mathrm{dir}}\right)$ and indirectly $\left(\mathrm{SEE}_{\text {indir }}\right)$. The latter was calculated from measurements of the $\mathrm{CO}_{2}$ production and $\mathrm{O}_{2}$ uptake and converted to energy expenditure using equation 19 from Elia \& Livesey (1992). Measurements are given as the mean value of all the measured SEE during the last $3 \mathrm{~h}$ of sleep. $\mathrm{SEE}_{\text {dir }}$ was corrected for the nightly drop in body temperature by measurements of rectal temperature before entering the chamber and on the following morning. The drop in core temperature was assumed to be linear during the sleeping period, and the distribution between core and shell was considered constant overnight. The calorimeter chamber was kept at $28^{\circ} \mathrm{C}$. Details of the chamber are given elsewhere (Faber et al. 1998). Daily calibrations of the direct measurements and the flow through the chamber were performed with an electrical dummy and evaporation from a water tank placed on a scale in the chamber. Calibrations of the indirect measurements were performed daily with calibrations of the $\mathrm{O}_{2}$ and $\mathrm{CO}_{2}$ analysers using air with a known content as measured by the micro-Scholander technique (Scholander, 1947).

Faeces and urine. All faeces and urine were collected during phase 3 . The urine was kept cold $\left(0^{\circ} \mathrm{C}\right)$, and once a day urine from the last $24 \mathrm{~h}$ was weighed and a representative sample frozen for later analysis. Faeces were stored in plastic bags at $-18^{\circ} \mathrm{C}$ after being weighed. Before analysis, faeces were thawed and homogenised by a Stomacher Lab Blender ${ }^{\circledR}$ (Seward Medical Ltd, London, UK), and representative samples from each $24 \mathrm{~h}$ period were collected. The samples were freeze-dried and analysed for energy content by bomb calorimetry and for $\mathrm{N}$ content by the Kjeldahl method respectively. Analysis of the energy content of faeces for each day was determined for one subject, and showed an approximately constant energy content perg DM after day 3 . Therefore the analysis of faeces energy content on all other subjects was performed on pooled faeces samples from day $1-2$, day $3-7$, day $8-14$, and day 15 to the end of phase 3 . The energy content of protein in faeces was calculated from the $\mathrm{N}$ content (g) multiplied by 6.25 and by $23.6 \mathrm{~kJ} / \mathrm{g}$. Carbohydrate and fat content were calculated from residual energy assuming an energy value of $17.4 \mathrm{~kJ} / \mathrm{g}$ for carbohydrate and $39.3 \mathrm{~kJ} / \mathrm{g}$ for fat. The values reported are the mean of duplicate determinations.

Urine samples were analysed for $\mathrm{N}$ by the Kjeldahl method. Protein oxidation $(\mathrm{g})$ was calculated as urine $\mathrm{N}$ excretion $(\mathrm{g})$ multiplied by $6 \cdot 25$.

Hepatic de novo lipogenesis. Fractional hepatic DNL, i.e. the percentage of total plasma VLDL-fatty acids synthesised de novo, was determined once in phase 2 and three times (i.e. once weekly) in phase 3 by mass isotopomer distribution analysis for pairs no. $2-10$ as described by Hellerstein et al. (1991) and Faix et al. (1993). In order to reach a near-steady state of $\left[{ }^{13} \mathrm{C}\right]$ acetyl-CoA labelling, $400 \mathrm{mg}\left[1-{ }^{13} \mathrm{C}\right]$ acetate, $99 \%$ enrichment, in approximately $50 \mathrm{ml}$ water was given orally every $60 \mathrm{~min}$ from $10.00-$ 19.00 hours. Blood samples were obtained at 10.00 hours while the subject was fasting and at 18.00, 19.00, 20.00 and 21.00 hours (non-fasting values) and were immediately centrifuged at $-5^{\circ} \mathrm{C}$ in order to separate plasma and erythrocytes. Plasma was stored at $-21^{\circ} \mathrm{C}$ until analysis. Before VLDL isolation from the plasma, chylomicrons were removed by centrifugation at $20^{\circ} \mathrm{C}$ for $20 \mathrm{~min}$ at $112500 \mathrm{~g}$ of $2 \mathrm{ml}$ plasma overlayered by $1.5 \mathrm{ml}$ salt solution (Mills et al. 1984). The lower $2.2 \mathrm{ml}$ was removed and layered under $2 \mathrm{ml}$ salt solution and centrifuged again at $20^{\circ} \mathrm{C}$ for $22 \mathrm{~h}$ at $300000 \mathrm{~g}$. The VLDL fraction (the top layer) was aspirated and used for determination of the concentration of VLDL and for mass isotopomer distribution analysis. The concentration of VLDL was measured by enzymatic glycerol determination (Wieland, 1984) after hydrolysis in ethanolic KOH (Kates, 1986). Mass isotopomer distribution analysis was carried out on methyl esters of the VLDL fatty acids, prepared by transesterification of a lipid extract as previously described (Hellerstein et al. 1991).

The rate constant of hepatic DNL was determined for pairs no. $7-10$ in phase 2 and at the end of phase 3 by 
measuring the incorporation of $\left[1-{ }^{13} \mathrm{C}\right]$ acetate in VLDLpalmitate over time (Hellerstein \& Neese, 1993). For that analysis $400 \mathrm{mg}\left[1-{ }^{13} \mathrm{C}\right]$ acetate, $99 \%$ enrichment, in approximately $50 \mathrm{ml}$ water was given orally every $45 \mathrm{~min}$ from 10.00-18.00 hours, and blood samples were obtained every $45 \mathrm{~min}$ from 10.00-18.00 hours and at 19.00, 20.00 and 21.00 hours. The fractional hepatic DNL $(\mathrm{F})$ was determined at each time point as described above, and the rate constant determined by curve-fitting of the time-course of $\mathrm{F}$ to the equation $\mathrm{F}=\mathrm{A}\left(1-\mathrm{e}^{-\mathrm{K}_{\mathrm{s}}(\mathrm{t}-\mathrm{L})}\right)$, where $\mathrm{A}$ is the asymptotic value of $\mathrm{F}$ at isotopic steady-state, $\mathrm{K}_{\mathrm{s}}$ the rate constant for VLDL synthesis, and $\mathrm{L}$ the lag-time for ${ }^{13} \mathrm{C}$-incorporation in VLDL-fatty acids (Hellerstein \& Neese, 1993). Total hepatic DNL was calculated as $0.75 \times \mathrm{K}_{\mathrm{s}} \times \mathrm{F} \times \mathrm{VLDL} \times \mathrm{MM}_{\mathrm{TG}}$ (Hellerstein \& Neese, 1993), where VLDL is the size of the VLDL-pool (in mol), calculated as the mean of the nonfasting concentration of triacylglycerol in VLDL multiplied by the plasma volume (assumed to be 0.04 times the body weight), and $\mathrm{MM}_{\mathrm{TG}}$ set at 850 as an average molecular mass for triacylglycerol to obtain the results in g lipid. The factor 0.75 takes into account the fraction of VLDL-fatty acids $(25 \%)$ that are essential fatty acids and thus cannot be synthesised de novo (Hudgins et al. 1996). Total hepatic DNL calculated in this way was multiplied by 1.33 to correct for less than complete isotopic equilibration due to the relatively short time of isotope administration (L Hudgins, M Hellerstein, R Neese, J Hirsch, unpublished results). No correction was attempted for the probably lower contribution of DNL to fatty acids other than palmitate.

Blood glucose, insulin and leptin. The plasma used for the study of hepatic DNL was also used for determination of glucose (Kunst et al. 1984), insulin and leptin by radioimmunoassays according to the protocol of the manufacturer (Coat-A-Count ${ }^{\circledR}$ Insulin, Diagnostic Products Corporation, Los Angeles, CA, USA and Linco Research Inc., St Charles, MO, USA).

\section{Statistical procedures}

Results are presented as mean values with standard errors of the means, and $P$-values were calculated by Student's $t$ test or the Mann-Whitney test as appropriate. Curve fittings were performed by GraphPad Prism, version 2.01 (GraphPad Software, Inc., San Diego, CA, USA).

\section{Ethics}

Each subject received a written as well as verbal instruction concerning the study. The study was approved by the ethical committee of Fyns and Vejle Amt, and a letter of consent was signed by each subject.

\section{Results}

\section{Energy intake}

Habitual food intake is shown in Table 2. Alcohol consumption in some of the subjects was high in phase 1 . The energy intake in phase 3 was in accordance with that intended; $78 \%$ from carbohydrates, $11 \%$ from fat and $11 \%$ from protein for the C-group and $31 \%, 58 \%$ and $11 \%$ for the F-group respectively. Alcohol was not included in the diet in phase 3, but if the subjects occasionally had visitors, a few drinks were allowed. The total intake is given as the mean value per day in Table 3. Energy intake was very similar in the C-and F-group during phase 3: $19 \cdot 3$ and $19.2 \mathrm{MJ} / \mathrm{d}$ respectively. On average the C-group had a surplus energy intake of 5.62 (SEM 0.50) MJ/d and the Fgroup of 4.78 (SEM 0.70 ) $\mathrm{MJ} / \mathrm{d}$, corresponding to an average increase of $37 \%$ in total energy intake.

The large amount of carbohydrate consumed by the Cgroup led to a substantial consumption of purified sucrose, from 20 to $36 \%$ of the total intake of carbohydrate. The percentage of energy from sucrose was 15-29 and thus within the range of sucrose consumption registered in Denmark (Danskernes kostvaner, 1996).

\section{Anthropometry}

Curve fitting of the time course of body weight and fat mass to linear-, power- or exponential functions showed that the time course was best described by a linear equation. Accordingly, changes in body weight, fat mass, fat free

Table 2. Energy intake per day during phase $1^{\text {* }}$

\begin{tabular}{|c|c|c|c|c|c|c|c|c|c|c|}
\hline \multirow[b]{2}{*}{ Subjects† } & \multicolumn{2}{|c|}{ Energy intake (MJ/d) } & \multicolumn{2}{|c|}{$\begin{array}{l}\text { Carbohydrate } \\
\text { intake }(\mathrm{MJ} / \mathrm{d})\end{array}$} & \multicolumn{2}{|c|}{ Fat intake $(\mathrm{MJ} / \mathrm{d})$} & \multicolumn{2}{|c|}{ Protein intake (MJ/d) } & \multicolumn{2}{|c|}{ Alcohol intake $(\mathrm{MJ} / \mathrm{d})$} \\
\hline & C-group & F-group & C-group & F-group & C-group & F-group & C-group & F-group & C-group & F-group \\
\hline Pair 1 & $18 \cdot 6$ & $18 \cdot 5$ & $9 \cdot 3$ & $8 \cdot 7$ & $5 \cdot 0$ & 0.2 & $2 \cdot 0$ & $2 \cdot 1$ & $2 \cdot 2$ & 0.8 \\
\hline Pair 2 & $15 \cdot 2$ & $15 \cdot 2$ & 8.9 & 6.9 & $4 \cdot 0$ & $4 \cdot 8$ & $2 \cdot 0$ & $2 \cdot 6$ & 0.3 & 1.5 \\
\hline Pair 3 & $12 \cdot 2$ & 14.5 & $6 \cdot 3$ & $6 \cdot 1$ & 4.5 & 3.6 & 1.6 & 1.4 & $1 \cdot 1$ & 3.5 \\
\hline Pair 4 & $12 \cdot 2$ & $15 \cdot 6$ & $7 \cdot 0$ & $6 \cdot 8$ & 3.4 & $6 \cdot 4$ & 1.5 & 2.4 & 0.2 & 0.0 \\
\hline Pair 5 & 8.9 & $11 \cdot 2$ & $5 \cdot 1$ & 5.5 & $2 \cdot 2$ & $3 \cdot 2$ & $1 \cdot 1$ & $1 \cdot 3$ & 0.5 & $1 \cdot 3$ \\
\hline Pair 6 & 13.5 & $13 \cdot 0$ & $7 \cdot 1$ & 6.9 & $4 \cdot 4$ & 3.9 & 1.7 & 1.7 & 0.2 & 0.4 \\
\hline Pair 7 & $15 \cdot 1$ & $11 \cdot 4$ & $10 \cdot 4$ & 5.9 & 2.7 & 3.8 & 2.0 & 1.5 & 0.0 & 0.2 \\
\hline Pair 8 & $10 \cdot 3$ & $10 \cdot 3$ & 5.0 & $4 \cdot 1$ & 2.5 & 2.0 & $1 \cdot 2$ & 1.0 & 1.6 & $3 \cdot 1$ \\
\hline Pair 9 & 14.4 & $20 \cdot 1$ & $8 \cdot 3$ & $11 \cdot 2$ & $4 \cdot 0$ & $6 \cdot 6$ & 1.6 & $2 \cdot 3$ & 0.6 & 0.0 \\
\hline Pair 10 & $16 \cdot 2$ & $13 \cdot 9$ & 8.7 & $6 \cdot 8$ & $4 \cdot 1$ & 3.7 & $2 \cdot 1$ & $2 \cdot 1$ & $1 \cdot 3$ & 1.4 \\
\hline Mean & $13 \cdot 7$ & 14.4 & $7 \cdot 6$ & 6.9 & 3.7 & 3.8 & $1 \cdot 7$ & 1.8 & 0.8 & $1 \cdot 2$ \\
\hline SEM & 0.9 & 0.9 & 0.5 & 0.6 & 0.3 & 0.6 & 0.1 & 0.2 & 0.2 & 0.4 \\
\hline
\end{tabular}

* Phase 1 (prephase) lasted 10-14 d. For details of measurement of energy intake see pp. 234-235.

† Subjects $(n 20)$ were paired according to habitual activity and body size. For details of subjects see Table 1. 
Table 3. Total intake per day of energy, carbohydrate, fat, protein and alcohol in phase 3 and increase in energy intake from phase 1 to phase 3 $(\Delta \text { Energy })^{\star}$

\begin{tabular}{|c|c|c|c|c|c|c|c|c|c|c|c|c|}
\hline \multirow[b]{2}{*}{ Subjects $†$} & \multicolumn{2}{|c|}{ Energy $(\mathrm{MJ} / \mathrm{d})$} & \multicolumn{2}{|c|}{$\begin{array}{l}\text { Carbohydrate } \\
\text { (MJ/d) }\end{array}$} & \multicolumn{2}{|c|}{ Fat $(\mathrm{MJ} / \mathrm{d})$} & \multicolumn{2}{|c|}{ Protein $(\mathrm{MJ} / \mathrm{d})$} & \multicolumn{2}{|c|}{ Alcohol (MJ/d) } & \multicolumn{2}{|c|}{$\Delta$ Energy $(\mathrm{MJ} / \mathrm{d})$} \\
\hline & C-group & F-group & C-group & F-group & C-group & F-group & C-group & F-group & C-group & F-group & C-group & F-group \\
\hline Pair 1 & 23.0 & $23 \cdot 1$ & $17 \cdot 6$ & $7 \cdot 2$ & $2 \cdot 6$ & $12 \cdot 9$ & $2 \cdot 4$ & 2.4 & 0.4 & 0.4 & 4.4 & 4.6 \\
\hline Pair 2 & $20 \cdot 7$ & 20.5 & 15.5 & $6 \cdot 3$ & $2 \cdot 2$ & 11.5 & $2 \cdot 2$ & $2 \cdot 1$ & 0.7 & 0.6 & 5.4 & 5.4 \\
\hline Pair 3 & $15 \cdot 7$ & 14.6 & $12 \cdot 2$ & 4.4 & 1.7 & 8.5 & 1.9 & 1.6 & 0.0 & 0.0 & 3.6 & 0.0 \\
\hline Pair 4 & 19.3 & 19.5 & 14.7 & $5 \cdot 6$ & $2 \cdot 0$ & $10 \cdot 7$ & $2 \cdot 0$ & $2 \cdot 1$ & 0.5 & 0.7 & $7 \cdot 2$ & 3.9 \\
\hline Pair 5 & $16 \cdot 8$ & 13.7 & 11.8 & 3.9 & 1.7 & 8.2 & 1.7 & 1.6 & 0.0 & 0.0 & 7.9 & 2.5 \\
\hline Pair 6 & 19.4 & 18.8 & $15 \cdot 0$ & 5.8 & $2 \cdot 1$ & $10 \cdot 9$ & $2 \cdot 2$ & $2 \cdot 1$ & 0.1 & 0.1 & $5 \cdot 8$ & 5.9 \\
\hline Pair 7 & $20 \cdot 2$ & $20 \cdot 3$ & $15 \cdot 7$ & $6 \cdot 2$ & $2 \cdot 2$ & 11.7 & $2 \cdot 2$ & $2 \cdot 3$ & 0.0 & $0 \cdot 1$ & $5 \cdot 1$ & 8.9 \\
\hline Pair 8 & $15 \cdot 3$ & $15 \cdot 8$ & 11.9 & $5 \cdot 2$ & 1.7 & 8.7 & 1.7 & 1.8 & 0.0 & 0.1 & 5.0 & 5.5 \\
\hline Pair 9 & $22 \cdot 6$ & $25 \cdot 5$ & $19 \cdot 6$ & $7 \cdot 7$ & 2.5 & $14 \cdot 8$ & $2 \cdot 6$ & $2 \cdot 8$ & 0.1 & 0.2 & $8 \cdot 2$ & $5 \cdot 4$ \\
\hline Pair 10 & $19 \cdot 8$ & $19 \cdot 6$ & $15 \cdot 5$ & $5 \cdot 8$ & $2 \cdot 1$ & 11.5 & $2 \cdot 1$ & $2 \cdot 3$ & $0 \cdot 1$ & $0 . \overline{0}$ & $3 . \overline{6}$ & $5 \cdot 7$ \\
\hline Mean & $19 \cdot 3$ & $19 \cdot 2$ & $15 \cdot 0$ & $5 \cdot 8$ & $2 \cdot 1$ & $10 \cdot 9$ & $2 \cdot 1$ & $2 \cdot 1$ & 0.2 & 0.2 & $5 \cdot 6$ & 4.8 \\
\hline SEM & 0.8 & $1 \cdot 1$ & 0.8 & 0.3 & 0.1 & 0.6 & 0.1 & $0 \cdot 1$ & 0.1 & 0.1 & 0.5 & 0.7 \\
\hline
\end{tabular}

* Phase 1 (prephase) lasted 10-14 d; phase 3 (intervention period) lasted $21 \mathrm{~d}$. For details of measurement of energy intake in phase 1 see pp. 234-235. In phase 3, energy intake was intended to be increased by $5 \mathrm{MJ}$ above habitual intake as determined in phase 1 (see pp. 234-235).

† Subjects $(n 20)$ were paired according to habitual activity and body size. For details of subjects see Table 1 . For details of C-and F-group diets in phase 3 see pp. 234-235.

mass and total body water were calculated from the daily measurements of weight and impedance by linear regression analysis (Table 4). The $\mathrm{C}$ - and the F-group showed a significant increase in body weight and fat mass of about similar size, 1.5 and $0.9 \mathrm{~kg}$ respectively, with no statistically significant differences between the groups. A significant change of fat free mass was only observed in the C-group. No changes were observed in total body water.

Mean values of the changes in fat mass and fat free mass determined by weekly underwater weighing are also given in Table 4. These values were similar to those obtained by impedance measurements, although gains in fat free mass were somewhat greater and gains in fat were somewhat lower than with impedance.

A considerable inter-individual variation in weight gain was observed in both groups, the CV being 97 and $82 \%$ in the $\mathrm{C}$ - and F-group respectively, despite an intended surplus energy intake of $5 \mathrm{MJ} / \mathrm{d}$ in all subjects. One reason for the variation in weight gain could be that some subjects underreported energy consumption in phase 1 . An indication of such under-reporting may be obtained by comparing the reported energy intake with the total energy expenditure as predicted by multiplication of BMR by a physical activity factor. With BMR calculated from age, height and weight of

Table 4. Changes in body composition (body weight, fat free mass, fat mass, and total body water) in phase 3 (intervention phase) using impedance and hydrostatic measurements $†$

\begin{tabular}{|c|c|c|c|c|c|c|c|c|}
\hline \multirow[b]{2}{*}{ Subjectsł } & \multicolumn{2}{|c|}{$\Delta$ Body weight $(\mathrm{kg})$} & \multicolumn{2}{|c|}{$\Delta$ Fat free mass $(\mathrm{kg})$} & \multicolumn{2}{|c|}{$\Delta$ Fat mass $(\mathrm{kg})$} & \multicolumn{2}{|c|}{$\Delta$ Total body water $(\mathrm{kg}$} \\
\hline & C-group & F-group & C-group & F-group & C-group & F-group & C-group & F-group \\
\hline \multicolumn{9}{|c|}{ Impedance measurements } \\
\hline Pair 1 & 2.25 & 3.24 & 1.08 & 1.51 & $1 \cdot 17$ & 1.73 & 1.03 & $1 \cdot 13$ \\
\hline Pair 2 & $2 \cdot 34$ & 3.48 & 1.50 & 1.61 & 0.84 & 1.87 & 1.01 & 1.09 \\
\hline Pair 3 & $-0 \cdot 10^{*}$ & 1.63 & -0.02 & 0.46 & $0.12^{*}$ & 1.17 & -0.25 & 0.15 \\
\hline Pair 4 & 2.58 & 2.91 & 1.25 & 1.25 & 1.33 & 1.66 & 0.95 & 0.99 \\
\hline Pair 5 & $-0.73^{*}$ & -0.71 & -0.79 & -1.09 & $0.06^{*}$ & 0.38 & -0.46 & -0.57 \\
\hline Pair 6 & $-0.59^{*}$ & $1.33^{*}$ & 0.08 & 0.75 & $-0.66^{\star}$ & $0.58^{*}$ & -0.25 & 0.34 \\
\hline Pair 7 & 1.40 & 2.00 & -0.03 & 0.50 & 1.42 & 1.50 & 0.00 & 0.00 \\
\hline Pair 8 & 2.05 & $-0.06^{*}$ & 1.07 & -0.11 & 0.98 & $0.06^{*}$ & 1.05 & -0.04 \\
\hline Pair 9 & $1 \cdot 12$ & $0.76^{*}$ & 0.49 & 0.32 & 0.64 & 1.08 & 0.27 & 0.04 \\
\hline Pair 10 & $3 \cdot 17$ & $1 \cdot 22$ & 1.51 & 0.43 & 1.66 & 0.79 & 1.28 & 0.61 \\
\hline Mean & 1.35 & 1.58 & 0.61 & 0.50 & 0.76 & 1.08 & 0.46 & 0.37 \\
\hline SEM & 0.42 & 0.41 & 0.23 & 0.25 & 0.22 & 0.19 & 0.20 & 0.17 \\
\hline$P \S$ & 0.010 & 0.006 & 0.030 & 0.090 & 0.009 & 0.001 & 0.060 & 0.070 \\
\hline \multicolumn{9}{|c|}{ Hydrostatic measurements } \\
\hline Mean & & & 1.33 & 0.85 & 0.86 & 0.83 & & \\
\hline SEM & & & 0.33 & 0.28 & 0.49 & 0.32 & & \\
\hline
\end{tabular}

* Slope of regression line not significantly different from zero.

$\dagger$ For details of procedures see pp. 234-235.

$\ddagger$ Subjects $(n 20)$ were paired according to habitual activity and body size. For details of subjects see Table 1 . For details of C- and F-group diets in phase 3 (21 d) see pp. 234-235.

$\S P$ values for changes in impedance measurements were obtained by testing the changes for being significantly different from zero. 
Table 5. Sleeping energy expenditure in phase 2 and in phase 3 (intervention phase)*

\begin{tabular}{|c|c|c|c|c|c|c|c|c|}
\hline \multirow[b]{4}{*}{ Subjects $†$} & \multicolumn{8}{|c|}{ Energy expenditure $(\mathrm{kJ} / \mathrm{h})$} \\
\hline & \multicolumn{4}{|c|}{ Direct method } & \multicolumn{4}{|c|}{ Indirect method } \\
\hline & \multicolumn{2}{|c|}{ C-group } & \multicolumn{2}{|c|}{ F-group } & \multicolumn{2}{|c|}{ C-group } & \multicolumn{2}{|c|}{ F-group } \\
\hline & Phase 2 & Phase 3 & Phase 2 & Phase 3 & Phase 2 & Phase 3 & Phase 2 & Phase 3 \\
\hline Pair 1 & 320 & 364 & 392 & 396 & 486 & 403 & 324 & 346 \\
\hline Pair 2 & 356 & 320 & 270 & 274 & 407 & 396 & 320 & 335 \\
\hline Pair 3 & 446 & nd & 266 & nd & 299 & 331 & 349 & 328 \\
\hline Pair 4 & 277 & 274 & 292 & 302 & 342 & 396 & 353 & 367 \\
\hline Pair 5 & 295 & 302 & 313 & 313 & 328 & 342 & 331 & 324 \\
\hline Pait 6 & 410 & 342 & 346 & 342 & 418 & 396 & 374 & 367 \\
\hline Pair 7 & 378 & 346 & 313 & 320 & 364 & 353 & 346 & 331 \\
\hline Pair 8 & nd & 302 & nd & 338 & nd & 331 & nd & 353 \\
\hline Pair 9 & 342 & 338 & 389 & 320 & 364 & 374 & 371 & 342 \\
\hline Pair 10 & 277 & 299 & 320 & 328 & 310 & 346 & 317 & 338 \\
\hline Mean & 345 & 321 & 322 & 326 & 368 & 367 & 343 & 343 \\
\hline SEM & 20 & 10 & 15 & 11 & 20 & 10 & 7 & 5 \\
\hline
\end{tabular}

the subjects (Schofield, 1985) and a physical activity factor of 1.78 as determined on free-living subjects by the doublelabelled water technique (Goldberg et al. 1991), there was no indication of under-reporting when the calculated means of the $\mathrm{C}$ - and the F-group were considered, but individual variation was large.

\section{Energy expenditure}

Mean SEE was measured by direct and indirect calorimetry and shown in Table 5. No changes over time in energy expenditure could be observed neither in the C-group nor in the F-group as a result of overfeeding (phase $2 v$. phase 3 ). Direct and indirect measurements of energy expenditure in the experimental period were in agreement in the F-group, but in the $\mathrm{C}$-group the results obtained by the indirect method were about $15 \%$ higher in both phase 2 and phase $3(P<0.002)$.

\section{Respiratory quotient}

The calculated RQ of food, the measured RQ during sleep, and the calculated non-protein RQ are given in Table 6. Food RQ was slightly higher than the measured RQ during phase 3 , both for the period as a whole and if comparisons were performed separately for week 1, 2 or 3 (data not shown). As expected, RQ was higher for the C-group than for the F-group. The measured values for RQ were stable from night-to-night and decreased on average by $0.01(P<$ 0.004) during the night, when compared hour-by-hour.

\section{Faeces, urine and nitrogen-balance}

The total DM content of faeces in phase 3 was $44 \%$ higher $(P=0.001)$ in the $\mathrm{C}$-group than in the F-group (Table 7). Also, the energy loss in faeces was $30 \%$ higher in the $\mathrm{C}$ group $(P=0.013)$. On average the $\mathrm{C}$-group lost $8.6 \%$ and

Table 6. Respiratory quotients (RQ) in phase 3 (intervention phase) of ingested food, during sleep and during sleep corrected for protein oxidation*

\begin{tabular}{lcccccccc}
\hline & \multicolumn{2}{c}{$R Q$ (food) } & & \multicolumn{2}{c}{$R Q$ (sleep) } & & \multicolumn{2}{c}{ Non-protein $R Q$} \\
\cline { 2 - 3 } Subjects & C-group & F-group & & C-group & F-group & & C-group & F-group \\
\hline Pair 1 & 0.93 & 0.80 & & 0.89 & 0.80 & & 0.90 & 0.79 \\
Pair 2 & 0.93 & 0.80 & & 0.89 & 0.82 & & 0.90 & 0.82 \\
Pair 3 & 0.94 & 0.80 & & 0.86 & 0.80 & & 0.87 & 0.79 \\
Pair 4 & 0.93 & 0.80 & & 0.80 & 0.75 & & 0.79 & 0.73 \\
Pair 5 & 0.94 & 0.80 & & 0.82 & 0.75 & & 0.82 & 0.73 \\
Pair 6 & 0.94 & 0.80 & & 0.79 & 0.74 & & 0.78 & 0.73 \\
Pair 7 & 0.94 & 0.80 & & 0.88 & 0.78 & & 0.89 & 0.76 \\
Pair 8 & 0.94 & 0.81 & & 0.86 & 0.75 & & 0.87 & 0.73 \\
Pair 9 & 0.94 & 0.80 & & 0.90 & 0.80 & & 0.91 & 0.79 \\
Pair 10 & 0.93 & 0.81 & & 0.94 & 0.81 & & 0.96 & 0.81 \\
Mean & 0.94 & 0.80 & & 0.86 & 0.78 & & 0.87 & 0.77 \\
SEM & 0.001 & 0.001 & & 0.01 & 0.01 & & 0.02 & 0.01 \\
\hline
\end{tabular}

* For details of procedures see pp. 234-236.

† Subjects (n 20) were paired according to habitual activity and body size. For details of subjects see Table 1. For details of C- and F-group diets in phase 3 (21 d) see pp. 234-235. 
Table 7. Loss in faeces of energy, dry matter, carbohydrate, fat and nitrogen during phase 3 (intervention phase)*

\begin{tabular}{|c|c|c|c|c|c|c|c|c|c|c|}
\hline \multirow[b]{2}{*}{ Subjects $†$} & \multicolumn{2}{|c|}{ Energy (MJ/d) } & \multicolumn{2}{|c|}{ Dry matter (g/d) } & \multicolumn{2}{|c|}{ Carbohydrate $(\mathrm{g} / \mathrm{d})$} & \multicolumn{2}{|c|}{ Fat $(g / d)$} & \multicolumn{2}{|c|}{ Protein (g/d) } \\
\hline & C-group & F-group & C-group & F-group & C-group & F-group & C-group & F-group & C-group & F-group \\
\hline Pair 1 & 2.05 & 1.86 & 97.00 & 74.62 & 61.24 & $37 \cdot 10$ & 8.76 & 21.29 & 27.02 & $16 \cdot 21$ \\
\hline Pair 2 & 1.86 & $1 \cdot 12$ & 83.67 & 46.62 & 48.81 & $21 \cdot 71$ & 12.05 & $10 \cdot 10$ & $22 \cdot 79$ & 14.79 \\
\hline Pair 3 & 1.32 & 0.97 & 59.67 & 40.71 & 32.00 & 19.90 & 7.29 & 8.38 & $20 \cdot 39$ & 12.44 \\
\hline Pair 4 & 1.71 & 1.66 & 77.48 & 62.86 & 32.76 & 25.00 & 18.00 & 21.43 & $26 \cdot 68$ & 16.40 \\
\hline Pair 5 & 1.23 & 0.75 & 53.90 & 32.00 & 28.52 & 15.62 & 8.86 & $5 \cdot 81$ & 16.47 & 10.57 \\
\hline Pair 6 & 1.66 & 1.32 & 72.43 & 51.95 & 38.29 & 22.05 & 12.24 & 14.48 & 21.92 & 15.42 \\
\hline Pair 7 & 1.66 & 1.47 & $76 \cdot 38$ & 61.00 & 43.86 & 29.14 & 8.24 & 13.43 & $24 \cdot 30$ & 18.46 \\
\hline Pair 8 & 1.43 & 0.96 & 67.90 & 43.05 & 42.76 & $22 \cdot 71$ & 5.76 & 5.43 & $19 \cdot 33$ & 14.88 \\
\hline Pair 9 & 1.80 & 1.25 & 82.19 & 55.38 & 48.19 & 30.52 & $10 \cdot 14$ & 8.29 & 23.84 & 16.59 \\
\hline Pair 10 & 1.35 & 1.02 & 63.38 & $42 \cdot 90$ & 36.67 & $20 \cdot 90$ & 4.95 & 9.00 & $21 \cdot 78$ & 12.99 \\
\hline Mean & 1.61 & 1.24 & 73.40 & $51 \cdot 11$ & $41 \cdot 31$ & 24.47 & 9.63 & $11 \cdot 76$ & 22.45 & 14.88 \\
\hline SEM & 0.08 & 0.11 & 4.04 & 3.99 & 3.10 & 1.96 & 1.20 & 1.84 & 1.03 & 0.73 \\
\hline
\end{tabular}

${ }^{*}$ For details of procedures see p. 235.

† Subjects $(n$ 20) were paired according to habitual activity and body size. For details of subjects see Table 1 . For details of C- and F-group diets in phase 3 ( $21 \mathrm{~d})$ see pp. 234-235.

the F-group $6.6 \%$ of the energy intake, a difference which was significant $(P=0.001)$. The content of carbohydrate, fat and protein in faeces is also given in Table 7. The loss of carbohydrate and protein was significantly higher $(P=0 \cdot 015$ and 0.0002 respectively) in the C-group, whereas the fat loss was the same in both groups.

The total intake of $\mathrm{N}$, the loss in faeces and urine, and the derived $\mathrm{N}$ balance are shown in Table 8. The $\mathrm{C}$ - and $\mathrm{F}$ groups had very similar protein intake. In the C-group the larger loss of $\mathrm{N}$ in faeces apparently was fully counterbalanced by a smaller loss in urine, resulting in a positive $\mathrm{N}$ balance of the same magnitude as in the F-group. Approximately $20 \%$ of the protein consumed was retained, resulting in an accumulation of about $430 \mathrm{~g}$ protein in both groups (cf. Table 8).

\section{Hepatic de novo lipogenesis}

Fractional hepatic DNL in phase 3 was 19.9 (SEM 1.5) \% and 3.3 (SEM 0.8 ) \% of total hepatic lipogenesis in the C-group and F-group respectively (Table 9, column 1). The timecourse of DNL in phase 3 is shown in Table 10. In the Cgroup, fractional hepatic DNL increased within the first week and remained at about $20 \%$ for the rest of the period. The fractional hepatic DNL in phase 2 was generally low except for C7, C10 and F10 (Table 10). These high values are not explicable by a habitual diet high in carbohydrate, except perhaps for $\mathrm{C} 7$ (Table 2), but may reflect large interindividual differences in hepatic lipogenesis (Aarsland et al. 1996).

Absolute hepatic DNL was estimated from the rate constant $\left(\mathrm{K}_{\mathrm{s}}\right)$ for VLDL synthesis as determined by the rate of $\left[1-{ }^{13} \mathrm{C}\right]$ acetate incorporation in VLDL palmitate, the fractional hepatic DNL, and the plasma concentration of VLDLtriacylglycerol. $\mathrm{K}_{\mathrm{s}}$ was $0.304(\mathrm{SEM} 0.051) \mathrm{h}^{-1}$ as measured for $\mathrm{C} 7$ to $\mathrm{C} 10$ at the end and for $\mathrm{C} 10$ at the start of phase 3 . This value was also used for the calculation of absolute DNL for C2 to C6. Furthermore, a constant rate of hepatic DNL equal to the rate in the measurement period (10.0021.00 hours) was assumed throughout the day. Calculated in

Table 8. Nitrogen intake, loss in faeces and urine and nitrogen balance in phase 3 (intervention phase)*

\begin{tabular}{|c|c|c|c|c|c|c|c|c|}
\hline \multirow[b]{2}{*}{ Subjects $†$} & \multicolumn{2}{|c|}{$\begin{array}{l}\text { Food nitrogen } \\
\text { intake }(\mathrm{g} / \mathrm{d})\end{array}$} & \multicolumn{2}{|c|}{$\begin{array}{l}\text { Faeces nitrogen } \\
\text { loss }(\mathrm{g} / \mathrm{d})\end{array}$} & \multicolumn{2}{|c|}{$\begin{array}{l}\text { Urine nitrogen } \\
\text { loss }(g / d)\end{array}$} & \multicolumn{2}{|c|}{$\begin{array}{l}N \text { balance } \\
(\mathrm{g} / \mathrm{d}) \ddagger\end{array}$} \\
\hline & C-group & F-group & C-group & F-group & C-group & F-group & C-group & F-group \\
\hline Pair 1 & $22 \cdot 3$ & $22 \cdot 5$ & $4 \cdot 3$ & $2 \cdot 6$ & $11 \cdot 3$ & $15 \cdot 0$ & $5 \cdot 8$ & $4 \cdot 1$ \\
\hline Pair 2 & $20 \cdot 7$ & $20 \cdot 0$ & $3 \cdot 7$ & $2 \cdot 4$ & $13 \cdot 4$ & $14 \cdot 3$ & $2 \cdot 8$ & 2.5 \\
\hline Pair 3 & 17.5 & $15 \cdot 5$ & $3 \cdot 3$ & $2 \cdot 0$ & 9.4 & $11 \cdot 7$ & $4 \cdot 1$ & $1 \cdot 2$ \\
\hline Pair 4 & $19 \cdot 1$ & $20 \cdot 0$ & 3.8 & $2 \cdot 6$ & 11.9 & 14.6 & $2 \cdot 6$ & $2 \cdot 0$ \\
\hline Pair 5 & 16.0 & 15.5 & 2.6 & 1.7 & 12.0 & $12 \cdot 0$ & 0.7 & 1.2 \\
\hline Pair 6 & $20 \cdot 2$ & $19 \cdot 6$ & 3.5 & 2.5 & $12 \cdot 4$ & $13 \cdot 6$ & 3.5 & $2 \cdot 7$ \\
\hline Pair 7 & 21.0 & 21.4 & 3.9 & 3.0 & 11.6 & $12 \cdot 1$ & 4.7 & 5.5 \\
\hline Pair 8 & $16 \cdot 1$ & $17 \cdot 3$ & $3 \cdot 1$ & $2 \cdot 4$ & 9.8 & 11.5 & $2 \cdot 6$ & $2 \cdot 7$ \\
\hline Pair 9 & 24.4 & $26 \cdot 2$ & 3.8 & $2 \cdot 7$ & $15 \cdot 0$ & $18 \cdot 7$ & 4.6 & 3.8 \\
\hline Pair 10 & 19.4 & 21.3 & 3.5 & $2 \cdot 1$ & 11.3 & 14.2 & 3.8 & $4 \cdot 1$ \\
\hline Mean & $19 \cdot 7$ & $19 \cdot 9$ & 3.6 & $2 \cdot 4$ & 11.8 & $13 \cdot 8$ & 3.5 & 3.0 \\
\hline SEM & 0.8 & 1.0 & 0.2 & $0 \cdot 1$ & 0.5 & 0.7 & 0.5 & 0.4 \\
\hline
\end{tabular}

${ }^{\star}$ For details of procedures see p. 235.

† Subjects $(n 20)$ were paired according to habitual activity and body size. For details of subjects see Table 1 . For details of C- and F-group diets in phase 3 (21 d) see pp. 234-235.

$\ddagger$ Values are corrected for skin nitrogen loss (4\% of protein intake; Bingham \& Cummings, 1985). 
this way, absolute hepatic DNL for phase 3 varied from 96 to $387 \mathrm{~g}$ (Table 9, column 3). These values are most likely overestimates, since the rate of hepatic DNL falls in the post-absorptive period (Davies et al. 1992; Hudgins et al. 1996).

\section{Total de novo lipogenesis}

At the whole-body level, DNL must have taken place if the amount of fat deposited is larger than the amount of fat available for storage. The latter can be calculated as the amount consumed minus the amount lost in faeces and minus the amount oxidised (Table 9, columns 4, 5 and 6). Fat oxidation was estimated from total non-protein energy expenditure and the non-protein RQ. In the calculations we have assumed that no oxidation of fat took place during the daytime (i.e. $16 \mathrm{~h}$ ), since energy expenditure and RQ were only measured during sleep. This assumption is very unlikely to be true (even after heavy overfeeding with carbohydrate, fat oxidation did not stop totally (Clore et al. 1995)) and causes underestimation of total DNL. The possible overestimation of $\mathrm{N}$ balance (see p. 235) will give rise to an overestimation of total DNL of about $5 \%$. Total DNL was positive in six and negative in four of the subjects in the C-group with a mean value of $332 \mathrm{~g} / 21 \mathrm{~d}$ (Table 9, column 9).

Extrahepatic DNL (Table 9, column 10), calculated as total (column 9) minus hepatic DNL (column 3), was positive in four of the nine subjects with a mean value of $115 \mathrm{~g} / 21 \mathrm{~d}$.

\section{Very-low density lipoprotein}

In the C-group both the fasting and non-fasting values of blood VLDL concentration ( $\mu \mathrm{mol}$ triacylglycerol/ml plasma) were significantly higher in phase 3 than in phase

Table 10. Fractional hepatic de novo lipogenesis (DNL) for the Cand F-group ${ }^{\star}$

\begin{tabular}{|c|c|c|c|c|}
\hline \multirow[b]{2}{*}{ Subjects† } & \multirow[b]{2}{*}{ Phase 2} & \multicolumn{3}{|c|}{ Phase 3} \\
\hline & & Week 1 & Week 2 & Week 3 \\
\hline C2 & 4.0 & 21.5 & $32 \cdot 0$ & 19.5 \\
\hline C3 & 4.9 & 21.0 & 14.2 & $23 \cdot 6$ \\
\hline C4 & 1.7 & $12 \cdot 2$ & $29 \cdot 1$ & 24.6 \\
\hline C5 & 3.4 & 8.0 & $16 \cdot 6$ & $10 \cdot 3$ \\
\hline C6 & $2 \cdot 6$ & 18.9 & 29.4 & $12 \cdot 9$ \\
\hline C7 & 18.9 & 18.2 & $18 \cdot 7$ & $23 \cdot 2$ \\
\hline C8 & 8.4 & 18.3 & $25 \cdot 1$ & 14.4 \\
\hline C9 & $2 \cdot 0$ & 15.9 & $12 \cdot 4$ & $10 \cdot 8$ \\
\hline $\mathrm{C} 10$ & $17 \cdot 3$ & 17.9 & $24 \cdot 3$ & $20 \cdot 4$ \\
\hline F2 & $9 \cdot 3$ & $2 \cdot 8$ & 3.3 & $2 \cdot 2$ \\
\hline F3 & $2 \cdot 8$ & 2.3 & 3.5 & 3.8 \\
\hline F4 & 4.2 & 3.4 & 4.7 & $6 \cdot 1$ \\
\hline F5 & 2.3 & 1.0 & 0.4 & 0.9 \\
\hline F6 & 1.6 & 1.9 & $2 \cdot 1$ & 2.5 \\
\hline F7 & 1.8 & 1.4 & 1.6 & $2 \cdot 0$ \\
\hline F8 & 3.0 & 0.6 & 0.7 & 0.0 \\
\hline F9 & $6 \cdot 1$ & 0.9 & 4.0 & 4.5 \\
\hline F10 & $19 \cdot 6$ & 2.4 & 2.5 & $9 \cdot 7$ \\
\hline
\end{tabular}

${ }^{*}$ Fractional hepatic DNL was determined as described on p. 235 in phase 2 and at the end of each week of phase 3 (week 1,2 and 3). Results are mean of values determined at $18.00,19.00,20.00$ and 21.00 hours.

†For details of subjects see Table 1. For details of C- and F-group diets in phase 2 (baseline phase, 2-3d) and phase 3 (intervention phase, $21 \mathrm{~d}$ ) see pp. 234-235. 
2 (fasting values 1.08 (SEM 0.18) and 1.88 (SEM 0.30), and non-fasting values 1.64 (SEM 0.30) and 2.11 (SEM 0.29) respectively, $P=0.007$ and 0.0006 respectively). The corresponding values for the F-group were 1.46 (SEM 0.12) and 1.07 (SEM 0.22), and 2.07 (SEM 0.22) and 1.95 (SEM 0.33) respectively, i.e. no significant changes from phase 2 to phase 3.

\section{Glucose, insulin and leptin}

Fasting and non-fasting glucose concentrations were within the range of $4 \cdot 5-5 \cdot 1$ and $4 \cdot 8-5 \cdot 2 \mu \mathrm{mol} / \mathrm{ml}$ plasma respectively. No significant differences between the C- and the F-group or between phase 2 and phase 3 were observed.

The fasting and non-fasting insulin concentrations were 9-12 and 23-31 $\mu \mathrm{U} / \mathrm{ml}$ plasma respectively. No significant differences between the $\mathrm{C}$ - and the F-group or between phase 2 and phase 3 were observed.

Leptin concentration in each subject was calculated as the mean value of measurements at 10.00, 18.00, 19.00, 20.00 and 21.00 hours in order to eliminate the effects of diurnal variation. The leptin concentration ( $\mathrm{ng} / \mathrm{ml}$ plasma) in the Cgroup was 2.4 (SEM 0.2) in phase 2 and increased significantly $(P=0.028)$ in the intervention period to $3 \cdot 2$ (SEM 0.4). In the F-group the phase 2 values were similar to those of the C-group (2.5 (SEM 0.3)) but no significant changes could be observed in phase $3(2 \cdot 8$ (SEM 0.3) at the end of phase 3 ). When data from both groups were pooled a significant positive correlation $(P=0.0046)$ was observed between the increase in fat mass and the concentration of leptin (Fig. 1). This is in agreement with the findings of Considine et al. (1996), who found a strong positive correlation between serum leptin concentrations and the percentage of body fat.

\section{Discussion}

The present study demonstrates that overfeeding of isoenergetic amounts of carbohydrate and fat led to nearly the same increase in body weight and fat mass; that carbohydrate overeating resulted in a $2-10$-fold increase in the fractional hepatic DNL; that whole-body DNL in the subjects from the C-group was larger than hepatic DNL although highly variable among individuals, and that the amount of energy lost in faeces was about $30 \%$ higher in the C-group than in the F-group.

\section{Design of the study}

The present study introduces a design with pairs of subjects acting as 'Siamese' twins in order to keep the physical activity similar in each pair during the non-sleeping period of the intervention. Subjects complied well to the twindesign. Staff members controlled the twin-condition both during the daytime, in the evenings and at the weekends, and only very seldom was one absent. Consequently, the differences in physical activity between the subjects of each pair can be considered eliminated as a factor influencing the general conclusions of the investigation.

The data on energy and macronutrient intake, energy expenditure during sleep, urine and faeces composition, body weight, fat mass and fat free mass during the intervention period were all collected on a daily basis over the course of the 3-week experimental period (phase 3). With

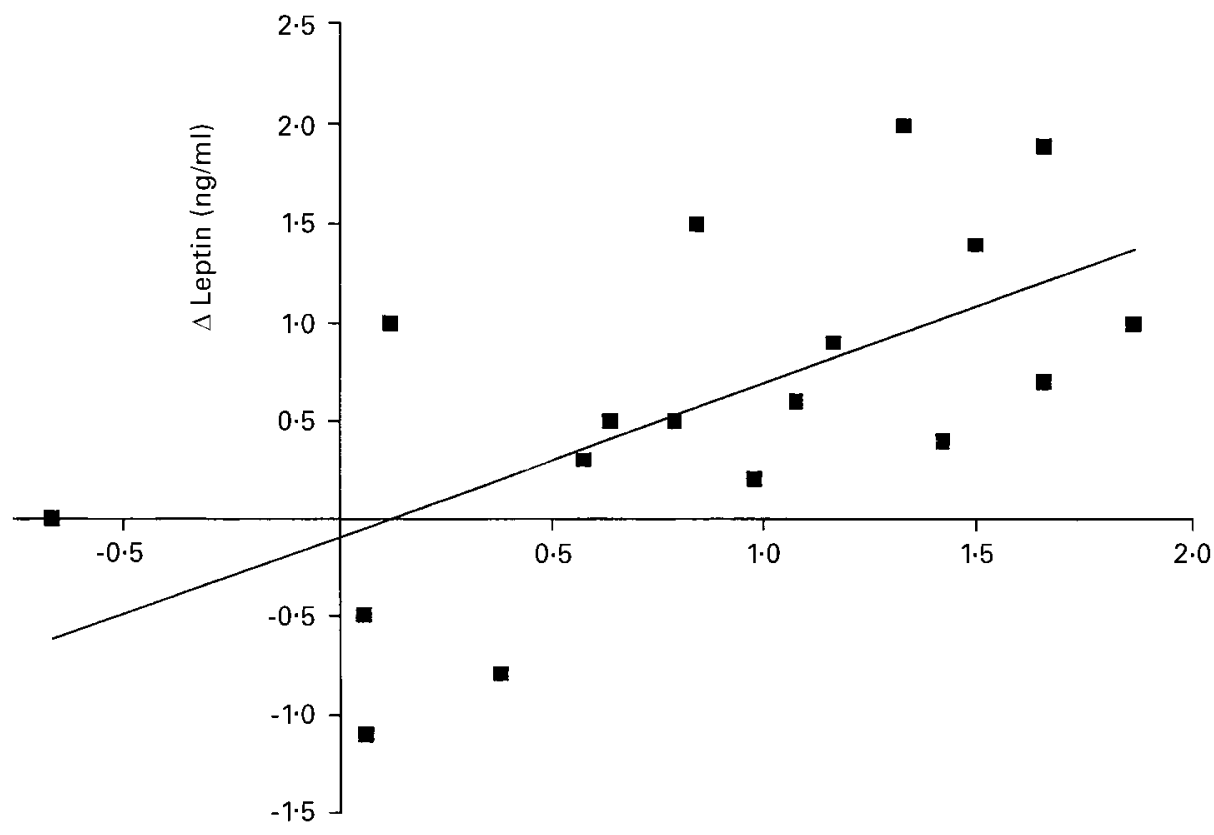

$\Delta$ Fat mass $(\mathrm{kg})$

Fig. 1. Correlation between change in fat mass and change in plasma leptin concentration in normal male subjects $(n 18)$ overfed by approximately $5 \mathrm{MJ} / \mathrm{d}$ for $21 \mathrm{~d}\left(y=0.79 x-0.10, r^{2} 0.40, P<0.005\right)$. For details of subjects see Table 1. Fat mass and leptin concentrations were determined as described on pp. 234-235. Leptin was not measured in two subjects (C1 and F1). 
exception of the collection of urine and faeces, any random variation in these variables will tend to cancel out, thereby not affecting the overall results. However, the advantage of determination of many values for each data point does not apply to the baseline data on energy intake in phase 1 (the weighing and registering of all food eaten) and to the data obtained in phase 2, where body composition, energy expenditure at sleep, urine, faeces, and blood variables were only determined once.

\section{Body composition}

Weight gain. In the present investigation the increase in body weight $(1.5 \mathrm{~kg})$ showed a considerable variation, the $\mathrm{CV}$ being high (97 and $82 \%$ in the $\mathrm{C}$ - and F-group respectively). No statistically significant difference in weight gain $(1.5 \mathrm{~kg})$ could be demonstrated between the $\mathrm{C}$ - and F-group. Similar results were obtained by Horton et al. (1995) (see p. 234). The results are in accordance with the concept that in the long-term only the energy content of the diet counts, and that the quality of the surplus of energy consumed is of little importance for the weight change. Supporting this notion are the findings of Golay et al. (1996) that underfeeding of normal or obese persons on a high-fat or an isoenergetic high-carbohydrate diet resulted in the same weight loss, and those of Schrauwen et al. (1997) that a change from a lowfat to a high-fat diet in normal persons did not change the body weight, provided that energy intake was unaltered. In contrast, it has been claimed that chronic imbalance between intake and oxidation is more likely if the surplus is given as fat (Bennett et al. 1992; Swinburn \& Ravussin, 1993). This view is in accordance with the notion that recently ingested macronutrients are oxidised in the order protein and carbohydrate followed by fat (Jebb et al. 1996; Stubbs, 1998). Nevertheless, since there appears to be no hard evidence for a carbohydrate induced 'luxuskonsumption' (Stubbs, 1998; present study), an increased intake of carbohydrate would be expected to result in a correspondingly increased carbohydrate oxidation, which in turn would cause a larger part of the ingested fat to be deposited. A carbohydrate intake larger than the amount which can be oxidised will cause deposition of glycogen and/or fat by DNL.

In earlier studies of overfeeding most authors have found a CV in the weight gain of 15-25\% (Ravussin et al. 1985; Forbes et al. 1986; Bandini et al. 1989; Roberts et al. 1990; Diaz et al. 1992; Pasquet et al. 1992) whereas Horton et al. (1995) and Dallosso \& James (1984) found variations similar to those of the present study. One reason for the large CV of the measured weight gain in the present study could be that weighing of the food eaten in phase 1 (ad libitum period) caused some of the subjects to eat less than usual. Furthermore, the relatively small weight gain in the present study combined with individual variation in tendency to deposit fat during overconsumption (Bouchard et al. 1990) may contribute to the large variation.

Fat and fat free mass. Fat mass increased significantly in both groups (Table 4), while only the C-group showed a significant increase in fat free mass, corresponding to $45 \%$ of the increase in body weight, which is in accordance with earlier investigations (Forbes et al. 1986; Diaz et al. 1992;
Pasquet et al. 1992; Tremblay et al. 1992). In addition, the $\mathrm{CV}$ for measurements of fat mass and fat free mass were high. From the measured gain in fat free mass (by impedance) of about $0.5 \mathrm{~kg}$, a N balance of $17 \mathrm{~g} \mathrm{~N}$ is expected, disregarding accumulation of glycogen. This is much less than found (Table 8). The reason for the discrepancy may be, at least partly, that collection of urine during phase 3 was not quantitative, in accordance with a large CV (40\%) for the daily volume of urine in the single individual (data not shown). This factor might well account for the approximately $3 \mathrm{~g}$ N/d losses not found here. Agreement between the measured gain in fat free mass and the $\mathrm{N}$ balance data would otherwise require a $30 \%$ higher protein oxidation rate than was actually found.

\section{Energy accounting}

SEE did not change from phase 2 to phase 3. Roberts et al. (1990) in an overfeeding study found an increase of $24 \mathrm{~h}$ resting metabolic rate of $7 \%$, whereas the resting metabolic rate was unchanged during fasting. Other investigations (Dallosso \& James, 1984; Ravussin et al. 1985) have estimated that overfeeding can be expected to give a $2-3 \%$ increased BMR per kg of weight gain. In the present study this would correspond to BMR changes of $3-5 \%$, which is of the same order of magnitude as the accuracy of the energetic measurements and would therefore not be detected. There was a disagreement in data for energy expenditure by the indirect and direct method for the C-group, which presently is not understood. Since the data for the F-group agreed, the discrepancy is unlikely to stem from the analytical procedures.

Respiratory quotient. In the present experiment RQ was determined during sleep only. As expected RQ in the Cgroup was significantly higher than in the $F$-group. $R_{\text {sleep }}$ did not change during the $21 \mathrm{~d}$ intervention, and remained smaller than $\mathrm{RQ}_{\text {food }}$ both in the $\mathrm{C}$ - and in the F-group. This is in contrast to the observation of Schrauwen et al. (1997) that the average daily RQ in subjects in energy balance equalled $\mathrm{RQ}_{\text {food }} 8 \mathrm{~d}$ after switching to a high-fat diet. This discrepancy can probably be related to the fact that RQ is lower during sleep than in the daytime (Dallosso \& James, 1984; Lean \& James, 1988) and that subjects in the present study were not in energy balance.

\section{Loss of energy in faeces}

Although the two diets were isoenergetic, the total loss of energy in faeces was significantly higher in the C-group $(7.8 \mathrm{MJ} / 21 \mathrm{~d}$; if not lost this would correspond to an increase in body mass of about $0.23 \mathrm{~kg}$ (7800/33.8; Forbes et al. 1986)).

There was no simple correlation between intake and loss in faeces of the various food components. Total intake of carbohydrate was $258 \%$ of energy higher in the C-group than in the F-group. However, the loss in faeces of carbohydrate was only $169 \%$ of energy higher in the C-group. The larger loss of carbohydrate in the C-group is in accordance with a larger intake of fibres in that group $(5 \cdot 25 \mathrm{~g} / \mathrm{MJ}$ per $\mathrm{d} v .2 \cdot 66 \mathrm{~g} / \mathrm{MJ}$ per $\mathrm{d}$ in the F-group). No significant difference was observed in the loss of lipid between the two 
groups although the total lipid intake was $519 \%$ of energy higher in the F-group. Furthermore, although protein intake was identical in the two groups, the C-group had a $51 \%$ higher loss of protein in faeces than the F-group.

\section{Hepatic de novo lipogenesis}

The fraction of fatty acids in VLDL synthesised by DNL was about $20 \%$ in the C-group and as expected very low in the F-group (Table 9) and did not change significantly during the last 2 weeks of phase 3 (Table 10). Fractional hepatic DNL was increased in all nine investigated Csubjects, even in C6 who lost fat mass, and the increase seems to be a response to consumption of carbohydrate, especially simple sugars (Hudgins et al. 1996, 1998). Most reported values of fractional hepatic DNL under conditions of 'eucaloric' energy intakes are below 5\% (Hellerstein, 1999), and under conditions of carbohydrate overfeeding are 20-40\% (Neese et al. 1995; Schwarz et al. 1995; Aarsland et al. 1997) as reported here.

Absolute hepatic DNL varied between 96 and $387 \mathrm{~g}$ per $21 \mathrm{~d}$ with a mean value of $211 \mathrm{~g}$ (Table 9). These values are maximum values (see p. 240). Aarsland et al. (1996) reported values of similar but somewhat lower magnitude (average value for five subjects corresponding to $60 \mathrm{~g}$ per $21 \mathrm{~d}$, range $15-144 \mathrm{~g}$ ).

\section{Total and extrahepatic de novo lipogenesis}

Total DNL was positive for six of the ten C-subjects (mean $332 \mathrm{~g}$ per $21 \mathrm{~d}$ ) and showed large inter-individual variation (Table 9). As discussed on p. 240 the calculated values for whole-body DNL provide minimum values. Aarsland et al. (1997) estimated whole-body DNL after $4 \mathrm{~d}$ of massive enteral plus parenteral carbohydrate overfeeding, representing 2.5 times normal energy expenditure, and found wholebody DNL to be about $170 \mathrm{~g} / \mathrm{d}$, and on the basis of data from Pasquet et al. (1992) under massive overfeeding (i.e. $6000 \mathrm{kcal}(25.1 \mathrm{MJ})$ as carbohydrate per d) a total DNL of at least $123 \mathrm{~g} / \mathrm{d}$ can be inferred. The degree of carbohydrate overfeeding in the present study was not as extreme as in the studies of Aarsland et al. (1997) or Pasquet et al. (1992), however.

The values for total DNL are net values, i.e. the balance between oxidation and de novo synthesis. For these reasons the true rate of total and extrahepatic DNL is probably higher than indicated in Table 9. It can be concluded that DNL is sufficient to account for about $40 \%$ of the increase in fat mass, and that extrahepatic DNL may account for about one-third of total DNL. Measurements of energy expenditure, RQ etc. during daytime would be desirable and would allow more precise conclusions regarding total and extrahepatic DNL.

It has been claimed that human subjects have a low capacity for DNL because of low activities of the enzymes involved in fatty acid synthesis (Acheson et al. 1982). Reported activities of fatty acid synthesis at $25^{\circ} \mathrm{C}$ are about $1 \mathrm{mU} / \mathrm{mg}$ protein in liver and adipose tissue of human subjects on a normal diet and somewhat higher in patients with long-term fat-free nutrition (Weiss et al. 1986). Assuming $1.5 \mathrm{~kg}$ liver with $200 \mathrm{mg}$ protein $/ \mathrm{g}$ wet weight and $10 \mathrm{~kg}$ adipose tissue with $40 \mathrm{mg}$ protein/g wet weight and that the enzyme activity at $37^{\circ} \mathrm{C}$ is twice that at $25^{\circ} \mathrm{C}$, it can be calculated that $1 \mathrm{mU} / \mathrm{mg}$ protein corresponds to a total capacity for fatty acid synthesis of $16 \mathrm{~g} / \mathrm{d}$ in the liver and $24 \mathrm{~g} / \mathrm{d}$ in adipose tissue, i.e. more than sufficient to account for the values measured in the present study.

By the process of DNL from carbohydrate there is an obligatory energy loss as heat of about $19 \%$ as compared to about $3 \%$ by the direct storage of dietary fat (Flatt, 1978). Therefore an interesting question is whether heat production associated with the glucose-to-fatty acid conversion is in excess, i.e. causes a corresponding increase in the overall metabolic turnover, or whether this heat is compensated for by a correspondingly smaller metabolic rate. If the latter mechanism is in operation weight gain could occur on a "per kilojoule' basis, independent of whether the source is fat or carbohydrate. If not, high carbohydrate intake may cause relatively less fat deposition. It should be noted that this contribution will be very small compared with the total energy turnover, and it would have been too small to detect. However, the present data indicate that weight gain and fat deposition caused by overconsumption may not be avoided by consuming a diet rich in carbohydrate and poor in fat.

\section{Acknowledgements}

Financial support was obtained from The Danish Medical Research Council (grant no. 9401044), The Novo Nordic Foundation, The Danish Foundation for the Advancement of Medical Science and The Forskningspulje of University of Odense. Leptin measurements by Professor Oluf Pedersen, Novo Nordic A/S, are acknowledged. The engagement and co-operation of the subjects, and the expert technical assistance provided by Lis Frandsen, Susanne Johannessen, Jytte Madsen, Britt Thobo-Carlsen, Ida Tønnesen, and Hanne Wennicke is highly appreciated.

\section{References}

Aarsland A, Chinkes D \& Wolfe RR (1996) Contributions of de novo synthesis of fatty acids to total VLDL- triglyceride secretion during prolonged hyperglycemia/hyperinsulinemia in normal men. Journal of Clinical Investigation 98, 2008-2017.

Aarsland A, Chinkes D \& Wolfe RR (1997) Hepatic and wholebody fat synthesis in humans during carbohydrate overfeeding. American Journal of Clinical Nutrition 65, 1774-1782.

Acheson KJ, Flatt JP \& Jéquier E (1982) Glycogen synthesis versus lipogenesis after a 500 gram carbohydrate meal in man. Metabolism 31, 1234-1240.

Acheson KJ, Schutz Y, Bessard T, Anantharaman K, Flatt JP \& Jéquier E (1988) Glycogen storage capacity and de novo lipogenesis during massive carbohydrate overfeeding in man. American Journal of Clinical Nutrition 48, 240-247.

Acheson KJ, Schutz Y, Bessard T, Ravussin E, Jéquier E \& Flatt JP (1984) Nutritional influences on lipogenesis and thermogenesis after a carbohydrate meal. American Journal of Physiology 246, E62-E70.

Astrup A \& Raben A (1995) Carbohydrate and Obesity. International Journal of Obesity 19, Suppl. 5, S27-S37.

Bandini LG, Schoeller DA, Edwards J, Young R, Oh SH \& Dietz WH (1989) Energy expenditure during overfeeding in obese and nonobese adolescents. American Journal of Physiology 256, E357-E367. 
Bennett C, Reed GW, Peters JC, Abumrad NN, Sun M \& Hill JO (1992) Short-term effects of dietary-fat ingestion on energy expenditure and nutrient balance. American Journal of Clinical Nutrition 55, 1071-1077.

Bingham S \& Cummings JH (1985) Urine nitrogen as an independent validatory measure of dietary intake: a study of nitrogen balance in individuals consuming their normal diet. American Journal of Clinical Nutrition 42, 1276-1289.

Bouchard C, Tremblay A, Després JP, Nadeau A, Lupien PJ, Thériault G, Dussault J, Moorjani S, Pinault S \& Fournier G (1990) The response to long-term overfeeding in identical twins. New England Journal of Medicine 332, 1477-1482.

Clore JN, Helm ST, \& Blackward WG (1995) Loss of hepatic autoregulation after carbohydrate overfeeding in man. Journal of Clinical Investigation 96, 1967-1972.

Considine RV, Sinha MK, Heiman ML, Kriauciunas A, Stephens TA, Nyce MR, Ohannesian JP, Marco CC, McKee LJ, Bauer TL \& Caro JF (1996) Serum immunoreactive-leptin concentrations in normal-weight and obese persons. New England Journal of Medicine 334, 292-295.

Dallosso HM \& James WPT (1984) Whole body calorimetry studies in adult men. British Journal of Nutrition 52, 49-64.

Danskernes kostvaner (1996) Levnedsmiddelstyrelsen, Copenhagen.

Davies SP, Carling D, Munday MR \& Hardie DG (1992) Diurnal rhythm of phosphorylation of rat liver acetyl-CoA carboxylase by the AMP-activated protein kinase, demonstrated using freeze-clamping. European Journal of Biochemistry 203, 615623.

Diaz EO, Prentice AM, Goldberg GR, Murgatroyd PR \& Coward WA (1992) Metabolic response to experimental overfeeding in lean and overweight volunteers. American Journal of Clinical Nutrition 56, 641-655.

Elia M \& Livesey G (1992) Energy expenditure and fuel selection in biological systems: the theory and practice of calculations based on indirect calorimetry and tracer methods. In Metabolic Control of Eating, Energy Expenditure and the Bioenergetics of Obesity [AP Simopoulos, editor]. World Review of Nutrition and Dietetics 70, 68-131.

Faber P, Lammert O, Johansen O \& Garby L (1998) A fast combined direct and indirect calorimeter for human subjects. Medical Engineering \& Physics 20, 291-301.

Faix D, Neese R, Kletke C, Wolden S, Cesar D, Soutlangus M, Shackleton CHL \& Hellerstein MK (1993) Quantification of menstrual and diurnal periodicities in rates of cholesterol and fat synthesis in humans. Journal of Lipid Research 34, 2063 2075 .

Flatt JP (1978) The biochemistry of energy expenditure. Recent Advances in Obesity Research 2, 211-228.

Flatt JP (1987) The difference in storage capacities for carbohydrate and for fat, and its implications in the regulation of body weight. Annals of the New York Academy of Sciences 499, 104123.

Flatt JP (1995) Body composition, respiratory quotient, and weight maintenance. American Journal of Clinical Nutrition 62, $1107 \mathrm{~S}-1117 \mathrm{~S}$

Forbes G, Brown MR, Welle SL \& Lipinski BA (1986) Deliberate overfeeding in women and men: energy cost and composition of the weight gain. British Journal of Nutrition 56, 1-9.

Golay A, Allaz AF, Morel Y, de Tonnac N, Tankowa S \& Reaven G (1996) Similar weight loss with low- or high-carbohydrate diets. American Journal of Clinical Nutrition 63, 174-178.

Goldberg GR, Black AE, Jebb SA, Cole TJ, Murgatroyd PR, Coward WA \& Prentice AM (1991) Critical evaluation of energy intake data using fundamental principles of energy physiology: 1. Derivation of cut-off limits to identify underrecording. European Journal of Clinical Nutrition 45, 569581.
Hellerstein MK (1999) De novo lipogenesis in humans: metabolic and regulatory aspects. European Journal of Clinical Nutrition 53, Suppl. 1, S53-S65.

Hellerstein MK \& Neese R (1993) Mass isotopomer distribution analysis: a technique for measuring biosynthesis and turnover of polymers. American Journal of Physiology 263, E988-E1001.

Hellerstein MK, Schwarz JM \& Neese RA (1996) Regulation of hepatic de novo lipogenesis in humans. Annual Review of Nutrition 16, 523-557.

Hellerstein MK, Wu K, Kaempfer A, Kletke C \& Shackleton CHL (1991) Sampling the lipogenic hepatic acetyl-CoA pool in vivo in the rat. Journal of Biological Chemistry 266, 10912-10919.

Horton TJ, Drougas H, Brachey A, Reed GW, Peters JC \& Hill JO (1995) Fat and carbohydrate overfeeding in humans: different effects on energy storage. American Journal of Clinical Nutrition 62, 19-29.

Hudgins LC, Hellerstein M, Seidman C, Neese R, Diakun J \& Hirsch J (1996) Human fatty acid synthesis is stimulated by a eucaloric low fat, high carbohydrate diet. Journal of Clinical Investigation 97, 2081-2091.

Hudgins LC, Seidman CE, Diakun J \& Hirsch J (1998) Human fatty acid synthesis is reduced after the substitution of dietary starch for sugar. American Journal of Clinical Nutrition 67, 631-639.

Jebb SA, Prentice AM, Goldberg GR, Murgatroyd PR, Black AE \& Coward WA (1996) Changes in macronutrient balance during over- and underfeeding assessed by 12 -d whole-body calorimetry. American Journal of Clinical Nutrition 64, 259-266.

Jéquier E (1998) Effect of lipid oxidation on glucose utilisation in humans. American Journal of Clinical Nutrition 67, Suppl., S527-S530.

Kates M (1986) Techniques in Lipidology, p. 142. Amsterdam, New York, Oxford: Elsevier.

Kunst A, Draeger B \& Ziegenhorn J (1984) Glucose. UV-methods with hexokinase and glucose-6-phosphate dehydrogenase. In Methods of Enzymatic Analysis, vol. VI, pp. 504-510 [HU Bergmeyer, editor]. Weinheim, Deerfield Beach, Florida, Basel: Verlag Chemie.

Lean MEJ \& James WPT (1988) Metabolic effects of isoenergetic nutrient exchange over 24 hours in relation to obesity in women. International Journal of Obesity 12, 15-27.

Lissner L \& Heitmann BL (1995) The dietary fat: carbohydrate ratio in relation to body weight. Current Opinion in Lipidology 6, 8-13.

Mills GL, Lane PA \& Weech PK (1984) A Guidebook to Lipoprotein Techniques, pp. 20-64. Amsterdam, New York, Oxford: Elsevier.

Møller E \& Saxholt E (1996) Danish Food Composition Tables, 4th ed. Copenhagen: Levnedsmiddelstyrelsen.

Neese RA, Benowitz NL, Hoh R, Faix D, LaBua A, Pun K \& Hellerstein MK (1995) Metabolic interactions between surplus dietary energy intake and cigarette smoking or its cessation. American Journal of Physiology 267, E1023-E1034.

Nielsen K, Kondrup J, Martinsen L, Døssing H, Larsson B, Stilling B \& Jensen MG (1995) Long-term oral refeeding of patients with cirrhosis of the liver. British Journal of Nutrition 74, 557567.

Pasquet P, Brigant L, Froment A, Koppert GA, Bard D, de Garine I \& Apfelbaum M (1992) Massive overfeeding and energy balance in men: the Guru Walla model. American Journal of Clinical Nutrition 56, 483-490.

Ravussin E, Schutz Y, Acheson KJ, Dusmet M, Bourquin L \& Jéquier E (1985) Short-term mixed diet overfeeding in man: no evidence for "luxuskonsumption". American Journal of Physiology 249, E470-E477.

Roberts SB, Young VR, Fuss P, Fiatarone MA, Richard B, Rasmussen H, Wagner D, Joseph L, Holehouse E \& Evans WJ 
(1990) Energy expenditure and subsequent nutrient intakes in overfed young men. American Journal of Physiology 259, R461-R469.

Schofield WN (1985) Predicting basal metabolic rate, new standards and review of previous work. Human Nutrition: Clinical Nutrition 39C, Suppl. 1, 5-41.

Scholander PF (1947) Analyser for accurate estimation of respiratory gasses in one-half cubic centimeter-sample. Journal of Biological Chemistry 167, 235-250.

Schrauwen P, van Marken Lichtenbelt WD, Saris WHM \& Westerterp KR (1997) Changes in fat oxidation in response to a high-fat diet. American Journal of Clinical Nutrition 66, 276-282.

Schutz Y, Acheson KJ \& Jéquier E (1985) Twenty-four-hour energy expenditure and thermogenesis: response to progressive carbohydrate overfeeding in man. International Journal of Obesity 9, Suppl. 2, 111-114.

Schwarz J-M, Neese RA, Turner S, Dare D \& Hellerstein MK (1995) Short-term alterations in carbohydrate energy intake in humans. Journal of Clinical Investigation 96, 2735-2743.
Stubbs RJ (1998) Appetite, feeding behaviour and energy balance in human subjects. Proceedings of the Nutrition Society 57, 341-356.

Swinburn B \& Ravussin E (1993) Energy balance or fat balance? American Journal of Clinical Nutrition 57, Suppl., 766S-771S.

Tremblay A, Després JP, Thériault G, Fournier G \& Bouchard C (1992) Overfeeding and energy expenditure in humans. American Journal of Clinical Nutrition 56, 857-862.

Weiss SL, Hoffmann GE, Schreiber R, Andres H, Fuchs E, Körber E \& Kolb HJ (1986) Fatty-acid biosynthesis in man, a pathway of minor importance. Zeitschrift für Biologische Chemie HoppeSeyler 367, 905-912.

Wieland OH (1984) Glycerol. UV-method. In Methods of Enzymatic Analysis, vol. VI, pp. 504-510 [HU Bergmeyer, editor]. Weinheim, Deerfield Beach, Florida, Basel: Verlag Chemie.

Wolfe RR (1998) Metabolic interactions between glucose and fatty acids in humans. American Journal of Clinical Nutrition 67, Suppl., S519-S526. 